\title{
TIPE DAN GAYA KEPEMIMPINAN KEPALA MADRASAH DALAM MANAJEMEN BERBASIS SEKOLAH
}

\author{
Oleh: Yusnadi*
}

\begin{abstract}
Abstrak
Manajemen Berbasis Sekolah merupakan salah satu wujud dari reformasi pendidikan, yang menawarkan kepada sekolah untuk menyediakan pendidikan yang lebih baik dan memadai bagi para peserta didik. Sejalan dengan jiwa dan semangat disentralisasi serta otonomi dalam bidang pendidikan, kewenangan sekolah juga perlu didukung oleh seorang pemimpin yang mempunyai tipe dan gaya yang dapat menarik dan mempengaruhi semua orang yang dipimpinnya. Oleh karena itu sangat perlu untuk menelaah beberapa karakter tipe dan gaya yang memimpin sebuah sekolah yang baik dan sesuai dengan kemampuan yang dipunyai oleh sekolah.
\end{abstract}

Kata Kunci: tipe, gaya, kepemimpinan, dan manajemen berbasis sekolah

\section{A. Pendahuluan}

Manajemen Berbasis Sekolah merupakan salah satu wujud dari reformasi pendidikan, yang menawarkan kepada sekolah untuk menyediakan pendidikan yang lebih baik dan memadai bagi para peserta didik. Otonomi dalam manajemen merupakan potensi bagi sekolah untuk meningkatkan kinerja para staf, menawarkan partisipasi langsung kelompok-kelompok yang terkait, dan meningkatkan pemahaman masyarakat terhadap pendidikan. Sejalan dengan jiwa dan semangat disentralisasi serta otonomi dalam bidang pendidikan, kewenangan sekolah juga berperan dalam menampung konsensus umum yang meyakini bahwa sedapat mungkin keputusan seharusnya dibuat oleh mereka yang memiliki akses paling baik terhadap informasi setempat, yang bertanggungjawab terhadap pelaksanaan kebijakan, dan yang terkena akibat-akibat dari kebijakan tersebut.

Manajemen berbasis sekolah merupakan terjemahan dari Bahasa Inggris "school-based management". Istilah MBS pertama kali muncul di Amerika Serikat ketika masyarakat mulai mempertanyakan relevansi pendidikan dengan tuntutan dan perkembangan masyarakat setempat. MBS merupakan paradigma baru pendidikan, yang memberikan otonomi luas pada tingkat sekolah (pelibatan masyarakat) dalam kerangka kebijakan pendidikan nasional. Otonomi diberikan agar sekolah leluasa mengelola sumber daya dan

* Dosen tetap pada STAI Al Washliyah Barabai Kalimantan Selatan. 
sumber dana dengan mengalokasikannya sesuai dengan prioritas kebutuhan, serta lebih tanggap terhadap kebutuhan setempat. Pelibatan masyarakat dimaksudkan agar mereka lebih memahami, membantu, dan mengontrol pengelolaan pendidikan. (Mulyasa, 2003; 27).

Kebijakan nasional yang menjadi prioritas pemerintah harus pula dilakukan oleh sekolah. Pada sistem MBS, sekolah dituntut secara mandiri menggali, mengalokasikan, menentukan prioritas, mengendalikan, dan mempertanggungjawabkan pemberdayaan sumber-sumber, baik kepada masyarakat maupun pemerintah.

Kepemimpinan pendidikan merupakan perpaduan dari istilah kepemimpinan dan pendidikan. Kepemimpinan adalah persaingan dalam gaya (mempengaruhi) orang lain. Mereka yang lebih mampu menanamkan peranannya dalam mempengaruhi orang lain, maka dia akan berpeluang besar menjadi pemimpin. (Jawahir TanThowi, 2003; 32).

\section{B. Pengertian Kepemimpinan Kepala Madrasah dalam MBS}

Josep Massie dan John Douglas yang dikutip oleh Winardi "Leadership occurs when one person's induces to work toward some predetermine had objective." (Winardi, 1990; 54). Ordway Tead yang dikutip oleh Wahjosumidjo mengatakan "operated toward some goal with the come to find desirable" kepemimpinan adalah kegiatan mempengaruhi orang untuk bekerja sama yang mana mereka mewujudkan kerja sama untuk mencapai tujuan yang diinginkan". (Wahjosumidjo, 2002; 98).

Horold Koontz melalui karyanya principle of management memberikan pengertian sebagai berikut: "leadership is the art coordinating and motivating individual is and group to achieve desired ends" (Horold koontz, 1964; 145), kepemimpinan adalah seni/kemampuan untuk mengkoordinasikan dan menggerakkan seseorang individu atau kelompok ke arah pencapaian tujuan yang diharapkan. Sedangkan menurut Sondang P. Siagian kepemimpinan adalah "motor penggerak semua sumber dan alat-alat yang tersedia bagi suatu organisasi. (Sondang P. Siagian, 2004; 5). Tharik Muhammad As Suwadi posisi pemimpin itu di depan menjadi petunjuk, menjadi jalan kebaikan bagi rombongan yang dipimpin dan pengaruh kebaikan mereka. (Tharik Muhamad, 2005; 41).

Dalam pada itu M. Surya mengatakan bahwa pada umumnya kepemimpinan dapat diartikan sebagai suatu proses guna mempengaruhi kegiatan kelompok supaya teratur dalam tugasnya dan usahanya untuk mencapai tujuan dari ketiga pengertian tersebut, dapat disimpulkan bahwa kepemimpinan atau leadership adalah: proses kegiatan seseorang yang merupakan seni/kemampuan untuk mempengaruhi, mengkoordinasikan dan menggerakkan individu-individu supaya timbul kerja sama secara teratur dalam 
upaya mencapai tujuan bersama yang telah ditetapkan/dirumuskan. (Departemen Pendidikan Nasional, 2001; 88).

Berapa definisi kepemimpinan tersebut terdapat beberapa unsur dari kepemimpinan yaitu:

1. Ada orang-orang yang memimpin, mempengaruhi dan memberikan bimbingan.

2. Ada orang yang dipengaruhi atau pengikut seperti anggota organisasi, bawahan maupun kelompok yang mau dikendalikan.

3. Adanya kegiatan tertentu dalam menggerakkan bawahan untuk mencapai tujuan bersama

4. Adanya tujuan yang diperjuangkan melalui serangkaian tindakan.

Sedangkan pendidikan adalah merupakan kegiatan dinamis dalam kehidupan setiap individu yang mempengaruhi perkembangan fisiknya, mentalnya, emosinya, sosialnya dan etiknya. Dengan perkataan lain, pendidikan adalah suatu kegiatan dinamis yang mempengaruhi seluruh aspek kepribadian dan kehidupan individu. Jadi pendidikan bertujuan untuk mencapai kepribadian secara terpadu antara nilai kognitif, afektif dan psikomotorik. (Adang Heriawan, 1988; 2).

Dari pengertian kepemimpinan dan pendidikan secara umum di atas maka kepemimpinan pendidikan adalah segenap kegiatan dalam usaha mempengaruhi personal di lapangan pendidikan pada situasi tertentu agar mereka melalui usaha kerjasama, maupun bekerja dengan penuh tanggung jawab dan ikhlas demi tercapainya tujuan pendidikan yang telah ditetapkan. (Husna Asmara, 1998; 18).

Sedangkan istilah kepemimpinan kepala Madrasah dalam MBS merupakan perpaduan dari ketiga kata tersebut, mengandung arti cara atau usaha kepala madrasah dalam mempengaruhi, mendorong, membimbing, mengarahkan, dan menggerakkan guru, staf, orang tua siswa, dan pihak-pihak terkait untuk bekerja sesuai dengan tujuan. (Departemen Pendidikan dan Kebudayaan, 1999; 9). Sedangkan manajemen berbasis sekolah adalah model manajemen yang memberikan otonomi yang lebih besar kepada sekolah dan mendorong pengambilan keputusan partisipasi yang melibatkan secara langsung semua warga sekolah (guru, staf, kepala sekolah, karyawan, orang tua siswa dan masyarakat). (Departemen Pendidikan Nasional, 2001; 3)

Secara umum MBS bertujuan menurut Hadiyono, yang dikutip oleh Hasbullah untuk menjadikan sekolah lebih mandiri atau memberdayakan sekolah melalui pemberian kewenangan (otonomi). Fleksibalitas yang lebih besar oleh kepala sekolah dalam mengelola sumber daya, dan mendorong partisipasi warga sekolah dan masyarakat untuk meningkatkan mutu pendidikan. (Hasbullah, 2006; 15). Meskipun MBS menawarkan otonomi dan kebebasan yang besar kepada madrasah, namun tetap disertai tanggung jawab yang harus dipikul oleh sekolah, Sekolah tidak memiliki fasilitas untuk berjalan sendirian tanpa menghiraukan kebijakan prioritas dan standarisasi yang dirumuskan oleh pemerintah, karena bagaimana pun sekolah berada 
dalam sistem pendidikan nasional, pemerintah dalam hal ini berkewajiban membuat regulasi dan pengevaluasian pelaksanaannya. Pemerintah selaku eksekutif, memiliki kewenangan yang terbatas melalui telaah terhadap berbagai implementasi dan penyelenggaraan pendidikan. (Khairuddin S. Amrudin dan M. Irwan, 2006; 34).

Jadi berdasarkan uraian di atas dapat disimpulkan bahwa kepemimpinan kepala madrasah dalam MBS adalah usaha kepala madrasah dalam mempengaruhi, mendorong, membimbing, mengarahkan, mengkoordinasikan, menggerakkan dan menyelaraskan sumber daya yang tersedia dalam rangka pelaksanaan otonomi madrasah melalui tangan kepala madrasah melalui kerja sama dengan warga sekolah untuk mengelola sumber daya yang tersedia dengan mengalokasikannya sesuai potensi dan kebutuhan sekolah serta kebutuhan masyarakat dengan cara mendorong pengambilan keputusan partisipasi yang melibatkan secara langsung warga madrasah yang ada hubungannya dengan pelaksanaan dan pengembangan pendidikan dan pengajaran agar tujuan yang telah ditetapkan dapat berjalan lancar secara efektif dan efisien.

Manajemen Berbasis Sekolah yang ditandai dengan otonomi sekolah dan pelibatan masyarakat merupakan respon pemerintah terhadap gejala-gejala yang muncul di masyarakat, bertujuan untuk meningkatkan efisiensi, mutu, dan pemerataan pendidikan. Peningkatan efisiensi, antara lain, diperoleh melalui keleluasaan mengelola sumber daya partisipasi masyarakat dan penyederhanaan birokrasi.

Sementara peningkatan mutu dapat diperoleh, antara lain, melalui partisipasi orang tua terhadap sekolah, fleksibilitas pengelolaan sekolah dan kelas, peningkatan profesionalisme guru dan kepala sekolah, berlakunya sistem insentif serta disinsetif. Peningkatan pemerataan antara lain diperoleh melalui peningkatan partisipasi masyarakat yang memungkinkan pemerintah lebih berkonsentrasi pada kelompok tertentu. Hal ini dimungkinkan karena pada sebagian masyarakat tumbuh rasa kepemilikan yang tinggi terhadap sekolah.

\section{Tipe Kepemimpinan Kepala Madrasah Dalam MBS}

\section{Tipe Kepemimpinan Otoriter}

Tipe pemimpin otoriter adalah cara memimpin yang dikembangkan disebut working on his group kegiatan hanya melaksanakan perintah atasan. Bawahan tidak diberikan kesempatan untuk berinisiatif dan mengeluarkan pendapat-pendapatnya, karena hal itu dalam bekerja dianggap sebagai penyimpangan-penyimpangan, walaupun tidak mustahil kegiatan-kegiatan yang dilaksanakan lebih efektif dan efektifitas dibandingkan dengan perintah yang diberikan instruksi atau perintah atasan tidak boleh ditafsirkan dan harus dilaksanakan secara tertib dan konsekuensi tanpa membuat kesalahankesalahan. (Haderi Nawawi, 1993; 91 - 92). 
Dalam kepemimpinan yang otokratis, pemimpin bertindak sebagai diktator terhadap anggota-anggota kelompoknya. Baginya memimpin adalah menggerakkan atau memaksa kelompok. Kekuatan pemimpin yang otokriter hanya dibatasi oleh undang-undang. Penafsirannya sebagai pemimpin tidak lain adalah menunjuk dan memberikan perintah kewajiban bawahan atau anggota-anggotanya hanya mengikuti dan menjalankan tidak boleh membantah atau mengajukan saran. (Ngalim Purwanto, 1999; 48).

\section{Tipe kepemimpinan yang demokratis}

Merupakan tipe kepemimpinan mengacu pada hubungan. Di sini seorang pemimpin selalu mengadakan hubungan dengan yang dipimpinnya. Segala kebijaksanaan pemimpin adalah merupakan hasil musyawarah atau merupakan ide-ide yang konstruktif. Pemimpin sering turun ke bawah guna mendapatkan informasi yang akan berguna untuk membuat kebijakankebijakan selanjutnya.

Dalam tipe kepemimpinan ini, pemimpin pendidikan selalu menghargai anggota staf dan memberikan kesempatan kepada mereka untuk mengembangkan inisiatif dan daya kreasinya. Dalam kepemimpinan ini terdapat pendelegasian kekuasaan dan tanggung jawab kepada anggota staf yang dinilai mampu menjalankan tugas tertentu kemampuan yang didelegasikan. Dari konsep kepercayaan kemampuan akan prestasi orang lain, ia menaruh kepercayaan kepada anggota stafnya. Namun dalam lingkup pengawasan, dorongan, dan bimbingan pemimpin.

\section{Tipe kepemimpinan laissez faire}

Tipe kepemimpinan ini merupakan kebalikan dari tipe kepemimpinan otoriter pemimpin memberikan kebebasan seluas-luasnya kepada semua anggota staf. (Moch Idochi Anwar, 1986; 6). Guru-guru diberi kebebasan dalam menjalankan tugasnya, tanpa adanya pengawasan dari pihak kepala sekolah, pimpinan membiarkan mereka berinisiatif sendiri, membuat kebijakan sendiri dan mengatur strategi untuk melaksanakan tugasnya. Pemimpin tidak perlu memberikan dorongan, bimbingan, dan pengarahan dalam menjalankan tugas bawahan.

Semua proses kerja juga seolah-olah berlangsung tanpa keterlibatan pemimpin, pemimpin seolah-olah berada di luar kelompok. Pemimpin akan turun tangan jika ada anggota staf yang memimpin dapat memberikan saran dan pendapat, tetapi saran dan pendapat tidak selalu mengikat para anggota staf boleh dipakai tetapi boleh juga tidak dipakai. (Hendyat Soetopo dan Wastopo Soetopo, 1982; 284). 


\section{Gaya Kepemimpinan Kepala Madrasah}

Gaya Kepemimpinan adalah cara yang dipergunakan pemimpin dalam mempengaruhi para pengikutnya. gaya kepemimpinan merupakan norma perilaku yang digunakan seseorang pada saat orang tersebut mencoba mempengaruhi perilaku orang lain seperti yang ia lihat. Dalam hal ini usaha menyelaraskan persepsi di antaranya orang yang akan mempengaruhi perilaku dengan yang akan dipengaruhi menjadi amat penting kedudukannya.

Gaya kepemimpinan merupakan suatu pola perilaku seorang pemimpin yang khas pada saat mempengaruhi anak buahnya, apa yang dipilih oleh pemimpin untuk dikerjakan, cara pemimpin bertindak dalam mempengaruhi anggota kelompok membentuk gaya kepemimpinannya. Gaya kepemimpinan yang harus ditetapkan kepala sekolah sangat tergantung kepada situasi dan kondisi staf yang dipimpinnya. (Mulyasa, 2003; 108).

Jika menghadapi staf yang memiliki kemampuan baik dan motivasi kerja juga baik, maka gaya kepemimpinan delegatif paling efektif, artinya kepala sekolah banyak memberikan dukungan dan mendelegasikan wewenang kepada staf. Jika menghadapi staf yang memiliki kemampuan kerja yang baik, tetapi motivasi kerjanya kurang, maka gaya kepemimpinan partisipatif paling efektif. Artinya, kepala sekolah berpartisipasi aktif dalam mendorong staf untuk menggunakan kemampuan secara optimal. Jika menghadapi staf yang memiliki kemampuan yang kurang baik dan motivasi kerja yang baik. Maka gaya kepemimpinan konsultatif. Artinya, kepala sekolah banyak memberikan bimbingan sehingga kemampuan staf secara bertahap meningkat. Jika menghadapi staf yang memiliki kemampuan yang kurang baik dan motivasi kerja juga kurang baik, maka gaya kepemimpinan instruktif paling efektif. Artinya, kepala sekolah lebih banyak memberikan petunjuk yang spesifik dan secara ketat mengawasi staf dalam mengerjakan tugasnya.

Secara teoritis telah banyak dikenal gaya kepemimpinan, namun gaya mana yang terbaik tidak mudah untuk ditentukan. Untuk memahami gaya kepemimpinan, sedikitnya dapat dikaji dari tiga pendekatan utama, yaitu pendekatan sifat, perilaku, dan situasional. (Mulyasa, 2003; 108).

Berikut ini dijelaskan ketiga pendekatan tersebut secara sederhana, sebagai berikut:

\section{Pendekatan Sifat}

Pendekatan sifat mencoba menerangkan sifat-sifat yang membuat seseorang berhasil. Pendekatan ini bertolak dari asumsi bahwa individu merupakan pusat kepemimpinan. Kepemimpinan dipandang sebagai sesuatu yang mengandung lebih banyak unsur individu, terutama pada sifat-sifat individu. Penganut pendekatan ini berusaha mengidentifikasikan sifat-sifat kepribadian yang dimiliki oleh pemimpin yang berhasil dan yang tidak berhasil. Pendekatan sifat berpendapat bahwa terdapat sifat-sifat tertentu, 
seperti kekuatan fisik atau keramahan yang esensil pada kepemimpinan yang efektif.

Sifat-sifat pribadi yang tak terpisahkan ini seperti inteligensi, dianggap bisa dialihkan dari satu situasi ke situasi yang lain. Karena tidak semua orang memiliki sifat-sifat ini, hanyalah mereka yang memiliki ini yang bisa dipertimbangkan untuk menempati kedudukan kepemimpinan. Dengan demikian, ada seorang pemimpin yang memiliki sifat-sifat bawaan yang membedakannya dari yang bukan pemimpin. Pendekatan ini menyarankan beberapa syarat yang harus dimiliki pemimpin yaitu:

a. kekuatan fisik dan susunan syaraf,

b. penghayatan terhadap arah dan tujuan,

c. antusiasme,

d. keramahtamahan,

e. integritas,

f. keahlian teknis,

g. kemampuan mengambil keputusan,

h. inteligensi,

i. keterampilan memimpin, dan

j. kepercayaan. (Mulyasa, 2003; 110).

\section{Pendekatan Perilaku}

Setelah pendekatan sifat kepribadian tidak mampu memberikan jawaban yang memuaskan, perhatian para pakar berbalik dan mengarahkan studi mereka kepada perilaku pemimpin. Studi ini memfokuskan dan mengidentifikasi perilaku yang khas dari pemimpin dalam kegiatannya mempengaruhi orang lain (pengikut). Pendekatan perilaku kepemimpinan banyak membahas keefektifan gaya kepemimpinan yang dijalankan oleh pemimpin.

\section{Pendekatan Situasional}

Pendekatan situasional hampir sama dengan pendekatan perilaku, keduanya menyoroti perilaku kepemimpinan dalam situasi tertentu. Dalam hal ini kepemimpinan lebih merupakan fungsi situasi dari pada sebagai kualitas pribadi, dan merupakan suatu kualitas yang timbul karena interaksi orangorang dalam situasi tertentu.

Menurut pandangan perilaku, dengan mengkaji kepemimpinan dari beberapa variabel yang mempengaruhi perilaku akan memudahkan menentukan gaya kepemimpinan yang paling cocok. Pendekatan ini menitikberatkan pada berbagai gaya kepemimpinan yang paling efektif diterapkan dalam situasi tertentu. 


\section{E. Simpulan}

Manajemen Berbasis Sekolah ditandai dengan otonomi sekolah dan pelibatan masyarakat merupakan respon pemerintah terhadap gejala-gejala yang muncul di masyarakat, bertujuan untuk meningkatkan efisiensi, mutu, dan pemerataan pendidikan. Peningkatan efisiensi, antara lain, diperoleh melalui keleluasaan mengelola sumber daya, partisipasi masyarakat dan penyederhanaan birokrasi. Oleh karena itu, diperlukan seorang pemimpin yang memahami beberapa gaya kepemimpinan, yaitu: otoriter, demokratis, dan laissez faire.

Gaya kepemimpinan merupakan suatu pola perilaku seorang pemimpin yang khas pada saat mempengaruhi anak buahnya, apa yang dipilih oleh pemimpin untuk dikerjakan, cara pemimpin bertindak dalam mempengaruhi anggota kelompok membentuk gaya kepemimpinannya. Untuk memahami gaya kepemimpinan, sedikitnya dapat dikaji dari tiga pendekatan utama, yaitu pendekatan sifat, perilaku, dan situasional 


\section{DAFTAR PUSTAKA}

Amrudin, Khairuddin S. dan M . Irwan, Manajemen Pendidikan Berbasis Sekolah, Jakarta: Quantum To Aching, 2006.

Asmara, Husna, Pengantar Kepemimpinan Pendidikan. Jakarta, Balai Aksara, 1998.

Burhanuddin, Analisis Administrasi Manajemen dan Kepemimpinan Pendidikan, Jakarta: Bumi Aksara. 1994.

Departemen Pendidikan Nasional, Manajemen Peningkatan Mutu Berbasis Sekolah, Jakarta: Tut Wuri Handayani, 2001.

Departemen Pendidikan, Panduan Manajemen Sekolah, Jakarta: DEPDIKBUD, 1999.

Harahap, Syahrir, Pendidikan Islam, Bandung: Remaja Rosdakarya, 1999.

Hasbullah, Otonomi Pendidikan, Jakarta, Grafindo Persada, 2006.

Idochi Anwar, Moch Kepemimpinan dalam Proses Belajar Mengajar, Bandung: Bumi Angsara, 1986.

Koontz, Horold, Principle of management, Hauston, Tex: Gulf, 1964.

Muhamad, Tharik, Sukses Menjadi Pemimpin Islam, Jakarta, Maghfirah, 2005.

Mulyasa, E, Manajemen Berbasis Sekolah: Konsep, Strategi dan Implementasi, Bandung: Remaja Rosdakarya, 2002.

-------------, Menjadi Kepala Sekolah Profesional dalam Konteks Menyukseskan MBS dan KBK, Bandung, Remaja Rosdakarya, 2004.

Nawawi, Haderi Administrasi Pendidikan, Jakarta: Haji Masagung, 1993.

Sergiovvani, Educational Governance and Administration, New Jersey: prentice Hall Inc., 1987.

Sondang P. Siagian, Filsafat Administrasi, Jakarta: Bumi Aksara, 2004.

Sosilo Maryono, Manajemen Sumber Daya manusia, Yogyakarta: BPRE, 1994.

Purwanto, Ngalim, Administrasi dan Supervisi Pendidikan, Jakarta: Remaja Rosdakarya, 1999. 
Tanthowi, Jawahir, Unsur-Unsur Manajemen Menurut Al-Qur'an. Jakarta: Al Husna, 2003.

Undang-Undang Republik Indonesia No. 20 Tahun 2003 Tentang Sistem Pendidikan Nasional, Bandung: Citra Umbara, 2003.

Wahjosumidjo, Kepemimpinan Kepala Sekolah Tinjauan Teoritik dan Permasalahannya, Jakarta: Raja Grafindo Persada, 2002.

Welas, John and Josep Bondi, Principe of School Administration Columbus, Ocio: Charles E. Mirrill, 1983.

Winardi, Kepemimpinan dalam Manajemen, Jakarta: Rineka Cipta, 1990. 